\title{
Stage IA Esophageal Squamous Cell Carcinoma AJCC v7
}

National Cancer Institute

\section{Source}

National Cancer Institute. Stage IA Esophageal Squamous Cell Carcinoma A/CC v7. NCI

Thesaurus. Code C87780.

Stage IA includes: T1, N0, M0, G1, GX, Tumor location: Any. T1: Tumor invades lamina propria, muscularis mucosae, or submucosa. N0: No regional lymph node metastasis. M0: No distant metastasis. G1: Well differentiated. GX: Grade cannot be assessed-stage grouping as G1. Tumor location: Location of the primary cancer site is defined by the position of the upper (proximal) edge of the tumor in the esophagus. (AJCC 7th ed.) 